\title{
Evaluation of antioxidant and cytotoxic effect against cancer cells line of Angiopteris ferox Copel tuber and its compounds by LC-MS analysis
}

\author{
Syamsu Nur ${ }^{*}$ (D), Andi Nur Aisyah², Endang Lukitaningsih ${ }^{3}$, Rumiyati ${ }^{3}$, Rini Indriani Juhardi ${ }^{1}$, Rezkiawati Andirah ${ }^{1}$, \\ Andi Sitti Hajar ${ }^{1}$ \\ ${ }^{1}$ Department of Pharmaceutical Chemistry, Sekolah Tinggi Ilmu Farmasi Makassar, Makassar, Indonesia. \\ ${ }^{2}$ Department of Pharmaceutical Technology, Sekolah Tinggi Ilmu Farmasi Makassar, Makassar, Indonesia. \\ ${ }^{3}$ Department of Pharmaceutical Chemistry, Faculty of Pharmacy, Universitas Gadjah Mada, Yogyakarta, Indonesia.
}

\section{ARTICLE INFO \\ Received on: 29/10/2020 \\ Accepted on: 31/03/2021 \\ Available online: 05/08/2021}

Key words:

Angiopteris ferox Copel, antioxidant, cancer cells, cytotoxic, LC-MS.

\begin{tabular}{l}
\hline ABSTRACT \\
Angiopteris ferox Copel is one of the plants empirically used as an anticancer by the Dayak tribe, native people groups \\
in Indonesian Borneo, most of whom traditionally lived with maritime culture in West Kutai, Indonesia. The purpose \\
of this investigation was to determine antioxidant and cytotoxic effects from extract and fractions of $A$. ferox Copel \\
and to evaluate their chemical contents using the liquid chromatography-mass spectrometry (LC-MS) approach. $A$. \\
ferox Copel was extracted with ethanol and fractionation was done using various solvents. Extract and fractions were \\
evaluated to their antioxidant activity and cytotoxic effect against three types of cancer cell lines, that is, epithelioid \\
carcinoma, human colon cancer, and mammary gland breast cancer, and their chemical compounds by LC-MS. The \\
study exhibited that the ethyl acetate fraction has contributed to antioxidant with very strong activity and cytotoxic \\
with moderate activity against the three types of the cancer cell lines. LC-MS prediction shows that phenolic and \\
flavonoid groups compounds the response to their effect. Therefore, $A$. ferox Copel is very prospective to be developed \\
as anticancer although its sample still needs further testing.
\end{tabular}

\section{INTRODUCTION}

Cancer is a type of global illness that still attracts a lot of attention from researchers all over the world. This illness is characterized by the growth of cells in the build that cannot be controlled or even stopped (Abd El Hady et al., 2014; Greenwell \& Rahman, 2015; Ochwang'i et al., 2014). One of the main causes of abnormal cell development in the body is the formation of oxidative stress. Oxidative stress will modulate the becoming of reactive oxygen species containing hydroxyl radicals, hydrogen peroxide, and singlet oxygen which can cause various problems such as cancer (Abd El Hady et al., 2014; Abdel-Hady et al., 2018).

\footnotetext{
"Corresponding Author

Syamsu Nur, Department of Pharmaceutical Chemistry, Sekolah Tinggi Ilmu Farmasi Makassar, Makassar, Indonesia.

E-mail: syamsunur19@gmail.com
}

Cancer treatments that have been carried out are surgery, radiotherapy, chemotherapy, immunotherapy, targeted therapy, hormone of therapy, stem cell transplantation, and radiation therapy (Emens \& Middleton, 2015; Ghareeb et al., 2014; Helmy et al., 2013). The high cost of chemotherapy and cancer treatment is not comparable with the level of therapeutic success that has not been optimal and the use of synthetic drugs that can inhibit the accretion of cancer cells has side effects such as hair loss and decreased white blood cell counts as body defense agents (Eskander \& Tewari, 2015; Putram et al., 2017; Schwartsmann et al., 2002). Therefore, it is necessary to develop a chemopreventive agent that is more effective and efficient. One approach to finding chemopreventive compounds is through the exploration of natural materials mainly derived from plants (Desai et al., 2018; Hsiao et al., 2019).

One type of plant whose compounds are not yet widely known is the ferns. Ferns have been widely used, among others, as ornamental plants, vegetables, and medicinal materials. Paku 
atai merah (Angiopteris ferox Copel) tuber is one of the ferns from Indonesian tropical forests that are used as medicinal plants that have antioxidant properties. In East Kalimantan-Indonesia, $A$. ferox Copel tubers are empirically used as breast anticancer drugs and detoxification. Leaves, rods, and tubers of $A$. ferox Copel are treated by poach and drink the water. The tubers are powdered and mixed with rice flour and then placed on the sick body parts. The resin from the tubers can be used by rubbing it on the superficies of the skin that hurts (Nur et al., 2019).

Bioactivity-related information from $A$. ferox Copel tuber is still limited. But previous research has been done that $A$. ferox Copel tuber has antioxidant and anticancer activities. Nur et al. (2019) inform that ethyl acetate fraction (EAF) of $A$. ferox Copel tuber indicated the highest antiradical effect with inhibition concentration of $50 \%\left(\mathrm{IC}_{50}\right)$ level of 13,79 by 2,2 Diphenyl 1 picrylhydrazyl scavenging method and EAF of $A$. ferox Copel tuber also showed the highest iron reduction effect using the ferric reducing antioxidant power method of $387.5 \pm 6.41 \mu \mathrm{M} / \mathrm{g}$. Furthermore, the EAF of $A$. ferox Copel tuber also showed the highest toxicity activity using the brine shrimp lethality test method with a value of $19.56 \pm 7.35$. Based on the results of the literature search, it shows that the anticancer activity of $A$. ferox Copel tubers has not been widely carried out, especially in mammary gland breast cancer (MCF-7), human colon cancer (WiDr), and epithelioid carcinoma (HeLa) cancer cells. Tests conducted using three cancer lines with different tissue origin can provide information regarding the bioactivity profile of $A$. ferox Copel that has not been reported.

In this study, we reported the activity of the extract and its fraction of $A$. ferox Copel as an antioxidant with different mechanisms and its role as an anticancer. Extracts or fractions that have good activities as antioxidants and anticancer are then investigated for their chemical content using the liquid chromatography-mass spectrometry (LC-MS) approach. This research is expected to provide additional information to strengthen the results of previous studies conducted by Nur et al. (2019).

\section{MATERIALS AND METHODS}

\section{Chemical}

Angiopteris ferox Copel tuber, 2-2'azinobis (3-ethylbenzthiazoline-6-sulphonic acid) (ABTS), potassium persulfate, sodium nitroprusside, naphthalene diamine dichloride, glacial acetic acid, sulfanilamide, beta-carotene, linoleic acid, tween 20, phosphate buffer saline (PBS), 3-(4,5-dimethylthiazol2-yl)-2,5-diphenyltetrazolium bromide (MTT), Roswell Park Memorial Institute (RPMI) medium, fetal bovine serum, streptomycin, penicillin, sodium dodecyl sulfate, aqua bidestillata, acetonitrile, ethanol 96\%, EAF, n-hexane, quercetin, doxorubicin, and three types of cancer cell lines (HeLa, WiDr, and MCF-7) were obtained from Cancer Chemopreventive Research Center, Pharmacy Faculty, Universitas Gadjah Mada.

\section{Plant material}

Angiopteris ferox Copel tuber was collected from tropical Indonesian forests in East Kalimantan (Borneo), Indonesia. $A$. ferox Copel tuber species was identified in Plant Anatomy and Systematic Laboratories, Mulawarman University, Indonesia. The A. ferox Copel tubers collected were sorted to separate impurities and then cleaned by running water and dried at $40^{\circ} \mathrm{C}$ in the oven for 1-3 days.

\section{Extraction and fractionation}

The extraction and fractionation of $A$. ferox Copel tubers procedure were carried out by Nur et al. (2019). Dry sample powders of $A$. ferox Copel tuber were soaked with ethanol $96 \%$ solvent by maceration method and the mixtures were left at room temperature for 1 times 24 hours. After that, the filtrate was separated and the solvent evaporated by a rotary evaporator. Then the crude extract obtained was fractionated using organic solvents based on the solvent polarity, starting with n-hexane, EAF, and aqueous ethanol. Based on the fractionation process that has been carried out, hexane fraction (HF), EAF, and aqueous-ethanol fraction (AEF) were obtained.

\section{Phytochemical screening}

Extract and fractions $A$. ferox Copel tuber were determined for compounds using specific chemical reagents to determine flavonoid, saponin, tannin, phenolic, alkaloid, steroid, and terpenoid. The phytochemical screening following the methodology was described by Harborne (1998); Kokate (1997); Hossain et al. (2013); Nnanga et al. (2016).

\section{Antioxidant activity by ABTS assay}

Antioxidant effect of ethanol extract (CE) and its fraction of $A$. ferox Copel tuber was examined by scavenging radical ABTS (Arnao et al., 2001). ABTS radical solution was prepared by mixing a $2.75 \mathrm{mM}$ ABTS solution $(7.1015 \mathrm{mg}$ in $5 \mathrm{ml}$ distilled water) and $2.58 \mathrm{mM}$ potassium persulfate $(3.5 \mathrm{mg}$ in $5 \mathrm{ml}$ distilled water). The blend was incubated for 6 hours in a dark room and the volume is sufficient to $25 \mathrm{ml}$ with ethanol p.a. The next step is to make series dilution levels of each sample solution in the length of $1-1,000 \mu \mathrm{g} / \mathrm{ml}$. Each serial concentration was mixed with 1 $\mathrm{ml}$ of ABTS solution and then the volume was sufficiently mixed with ethanol to $5 \mathrm{ml}$; the blend was shaken and allowed to stand for 30 minutes in the dark room. $1 \mathrm{ml}$ of ABTS solution added with ethanol to $5 \mathrm{ml}$ was used as blank (only ABTS solution) and quercetin was used as a positive control (PC). The absorbance of sample, PC, and blank solution was measured by UV-Vis spectrophotometry at a wavelength of $752 \mathrm{~nm}$. The percentage inhibition value was represented by the following formula:

Percentage of inhibition $=\frac{(\text { Abs blank }- \text { Abs sample })}{\text { Abs blank }} \times 100 \%$

\section{Antioxidant activity by nitric oxide (NO) assay}

Antioxidant effect of $\mathrm{CE}$ and its fraction of $A$. ferox Copel tuber was examined by the NO method (Unuofin et al., 2018). Antioxidant activity examined by the NO method was carried out by preparing a $10 \mathrm{mM}$ sodium nitroprusside in $0.5 \mathrm{mM}$ PBS (pH 7.4) and Griess solution ( $0.33 \%$ sulfanilamide in $20 \%$ glacial acetic acid and mixed in $0.1 \% \mathrm{w} / \mathrm{v}$ naphthylene at a ratio of $1: 1$ ) as a reagent. A series of samples were made in the concentration range of $1-100 \mu \mathrm{g} / \mathrm{ml}$. Each series level was added with $1 \mathrm{ml}$ of sodium nitroprusside $10 \mathrm{mM}$. The blend was incubated at $27^{\circ} \mathrm{C}$ for 2.5 hours and after incubating, the mixture was added with Griess reagent. The volume was adequately mixed to $5 \mathrm{ml}$ with PBS. $1 \mathrm{ml}$ 
of sodium nitroprusside solution mixed with $1 \mathrm{ml}$ Griess solution and the blend was sufficient to $5 \mathrm{ml}$ with PBS (blank solution) while quercetin was used as a PC. The mixture was measured for absorption at a wavelength of $540 \mathrm{~nm}$. The equation below is used to estimate the percentage of NO inhibition of extracts and PC.

Percentage of inhibition $=\frac{(\text { Abs blank }- \text { Abs sample })}{\text { Abs blank }} \times 100 \%$

\section{Antioxidant activity by lipid peroxidation assay}

The antioxidant activity by lipid peroxidation of $\mathrm{CE}$ and its fraction of $A$. ferox Copel tuber was carried out based on the beta-carotene bleaching (BCB) method (Nur et al., 2017; Seladji et al., 2014). Beta-carotene solution was prepared by means of 2 $\mathrm{mg}$ of beta-carotene powder in $0.2 \mathrm{ml}$ of chloroform and added with $0.2 \mathrm{ml}$ of linoleic acid, $2 \mathrm{ml}$ of tween 20 (chloroform was evaporated under vacuum with $40^{\circ} \mathrm{C}$ temperature), and $100 \mathrm{ml}$ of distilled water and shaken until a clear solution was obtained. A series of concentrations of a sample solution of $5-1,000 \mu \mathrm{g} / \mathrm{ml}$ and quercetin (as comparison) solution of $2.5-100 \mu \mathrm{g} / \mathrm{ml}$ were prepared. Each $1 \mathrm{ml}$ of sample was added with $2 \mathrm{ml}$ of BCB reagent. The mixture was incubated for 20 minutes at a temperature of $50^{\circ} \mathrm{C}$ and the absorbance was observed at minute $0-120$ with 30 -minute intervals at a wavelength of $450 \mathrm{~nm}$. Determination of antioxidant activity was calculated based on the activity of differences in degradation of the test samples with degradation to control (only beta-carotene solution). The percentage of inhibition was calculated by the formula $(\%)=\ln \left(A_{0} / A_{120}\right) \times 1 / t \times 100$, where $A_{0}$ and $A_{120}$ are the absorbance of 0 and 120 minutes, respectively, and $t$ is the incubation period.

\section{Cytotoxic Activity by MTT Assay}

Cytotoxic activity testing on the $\mathrm{CE}$ and its fraction was carried out by the colorimetric method using MTT based on the research of Kuete et al. (2017). Cytotoxic testing was carried out using three cancer cell lines, namely, HeLa, WiDr, and MCF-7, obtained from the culture laboratory of the Faculty of Pharmacy, Universitas Gadjah Mada Yogyakarta, Indonesia. First, cancer cell lines were cultured on complete RPMI media (RPMI-1640 medium supplemented with 10\% fetal bovine serum and antibiotics added were 100 units $/ \mathrm{ml}$ penicillin and $100 \mu \mathrm{g} /$ $\mathrm{ml}$ streptomycin). Cell growth was observed and every day the media were replaced with complete RPMI media. After that, the cells fulfill the surface of the dish or confluent around $>80 \%$ of the cell was harvested. Secondly, the cells were then distributed to the well and incubated in an incubator which is flowed with $\mathrm{CO}_{2}$ at $37^{\circ} \mathrm{C}$ for 24 hours for cells to adapt and stick to the wells until the cells are ready to be treated. After incubation, the serial concentration of samples $(1-500 \mu \mathrm{g} / \mathrm{ml})$, doxorubicin as a PC, and media as negative control were treated and incubated for 24 hours of $\mathrm{CO}_{2}$ incubator at $37^{\circ} \mathrm{C}$. After the incubation period, cell media are removed and an MTT reagent with concentrations of $0.5 \mathrm{mg} / \mathrm{ml}$ was prepared. The MTT solution was distributed into the sample well, PCs well, and media control well of $100 \mu$ and reincubated for 4 hours in $\mathrm{CO}_{2}$ incubator at $37^{\circ} \mathrm{C}$. At the end of the incubation, an amount of $100 \mu \mathrm{l}$ sodium dodecyl sulfate $10 \%$ stopper solution was added, allowed to stand overnight, and the absorption was measured with a microplate reader at a wavelength of $595 \mathrm{~nm}$. The percentage of cells viable was calculated from the absorbance data obtained.

\section{Chemical compound analysis using LC-MS}

The most active samples (EAF) in the antioxidant and cytotoxic measurement were analyzed for active compounds using the LC-MS (Liquid Chromatography-Mass Spectrometry) instrument of the QMicro QAA 842 type and the Waters Quattro Micro MS-MS detector. The stock sample was dissolved in $5 \mathrm{ml}$ of solvent and $20 \mu \mathrm{l}$ was added to the reversed-phase $\mathrm{C} 18$ analytical column of $50 \times 2.1 \times 1.9 \mu \mathrm{m}$ particle sizes with a flow rate of $0.2 \mathrm{ml} /$ minute. The column temperature used was $50^{\circ} \mathrm{C}$ and the final time was 20 minutes. Separation of chemical compounds occurs in the column with the aid of a pump using a pressure of 300 Bar. The sample is converted into a gas phase which will be ionized under vacuum. The ions are accelerated by an electric or magnetic field, which is measured as the ratio of mass to charge $(\mathrm{m} / \mathrm{z})$. LC-MS analysis results were made based on prediction of compounds based on $\mathrm{m} / \mathrm{z}$ profiles from existing secondary data and compared with $\mathrm{m} / \mathrm{z}$ profiles resulting from the presentation of data from samples.

\section{RESULTS}

One of the important steps in an effort to reveal the resource potential of medicinal plants such as A. ferox Copel tuber is through phytochemical screening. The phytochemical screening of extract and fractions of $A$. ferox Copel was carried out by chemical reagent which can be seen in Table 1. Table 1 provides information that $\mathrm{CE}, \mathrm{EAF}$, and $\mathrm{AEF}$, each containing secondary metabolites of the phenolic, tannins, flavonoids, saponins, and terpenoids/steroids but there are absence of alkaloid compound groups, whereas in the HF, there were no positive results for the flavonoid, tannin, and alkaloid compounds.

The efficacy of extract and fractions of $A$. ferox Copel to reduce free radical was carried out using two methods, namely, ABTS radical and nitric oxide method. Both ABTS radical and NO radical scavenger as well as lipid peroxidation inhibition activities were expressed by an $\mathrm{IC}_{50}$. The $\mathrm{IC}_{50}$ was obtained by plotting the percentage of inhibition ( $y$-axis) with a concentration of test solution ( $x$-axis) and the result as shown in Table 2. Table 2 indicated that, among the ABTS, NO radical reduction and lipid peroxidation inhibition attain the result that the EAF has a low $\mathrm{IC}_{50}$ value $(19.55 \pm 0.03,35.59 \pm 0.87$, and $40.65 \pm 1.71)$ with very strong category activity followed by AEF $(72.03 \pm 0.63$ and $91.59 \pm 0.67)$ and $\mathrm{CE}(83.87 \pm 2.87$ and $93.89 \pm 0.59)$ with strong category activity for ABTS and NO assay but different results

Table 1. Phytochemical compounds of A. ferox Copel tuber.

\begin{tabular}{lcccc}
\hline Compounds assay & CE & HFf & EAFaf & AEF \\
\hline Flavonoid & + & - & + & + \\
Alkaloid & - & - & - & - \\
Tannin & + & - & + & + \\
Saponin & + & + & + & + \\
Steroid & + & + & + & + \\
Terpenoid & + & + & + & + \\
Phenolic & + & + & + & + \\
\hline
\end{tabular}

$+=$ positive results; $-=$ negative results 
Table 2. The antioxidant activities of $\mathrm{CE}$ and its fractions by radical ABTS and $\mathrm{NO}$ scavenger.

\begin{tabular}{ccccc}
\hline \multirow{2}{*}{ Sample } & \multicolumn{2}{c}{ Antioxidant activity $\left(\mathbf{I C}_{50} \boldsymbol{\mu g} / \mathbf{m l}\right)$} & \multirow{2}{*}{$\begin{array}{c}\text { Category } \\
\text { (Blois, 1958) }\end{array}$} \\
\cline { 2 - 4 } & ABTS radical & NO radical & BCB assay & \\
\hline CE & $83.87 \pm 2.87$ & $93.89 \pm 0.59$ & $24.65 \pm 1.92^{\mathrm{a}}$ & Strong \\
HF & $210 \pm 1.09$ & $204.97 \pm 0.37$ & $175.65 \pm 2.86$ & Weak \\
EAF & $19.55 \pm 0.03$ & $35.59 \pm 0.87$ & $40.65 \pm 1.71$ & Very strong \\
AEF & $72.03 \pm 0.63$ & $91.59 \pm 0.67$ & $216.7 \pm 0.81^{\mathrm{b}}$ & Strong \\
PC & $2.32 \pm 0.013$ & $9.44 \pm 0.083$ & $38.12 \pm 1.29$ & Very strong \\
\hline
\end{tabular}

The data of antioxidant activity were expressed by mean \pm SD in triplicate $(n=3)$. ${ }^{a}$ Shows different result (very strong).

${ }^{\mathrm{b}} \mathrm{s}$ Shows weak activity. occur in the BCB assay and $\mathrm{HF}(210 \pm 1.09,204.97 \pm 0.37$, and $175.65 \pm 2.86$ ) with weak category. The lower the $\mathrm{IC}_{50}$ value, the higher its antioxidant activity. However, the antiradical effects of extract and fractions were lesser than that of quercetin (2.32 \pm $0.013,9.44 \pm 0.083$, and $38.12 \pm 3.30$ ) as a PC with very strong activity.

The sample plant extract and fractions from A. ferox Copel tuber were examined the cytotoxicity effect as anticancer against three cancer cell lines, that is, HeLa, WiDr, and MCF-7 compared with doxorubicin as a PC. The results of the cytotoxic test from the extract and fraction of $A$. ferox Copel tuber can be seen in Figure 1. Figure 1 indicated that the cytotoxic effect of the extract and fractions of $A$. ferox Copel tuber on three types
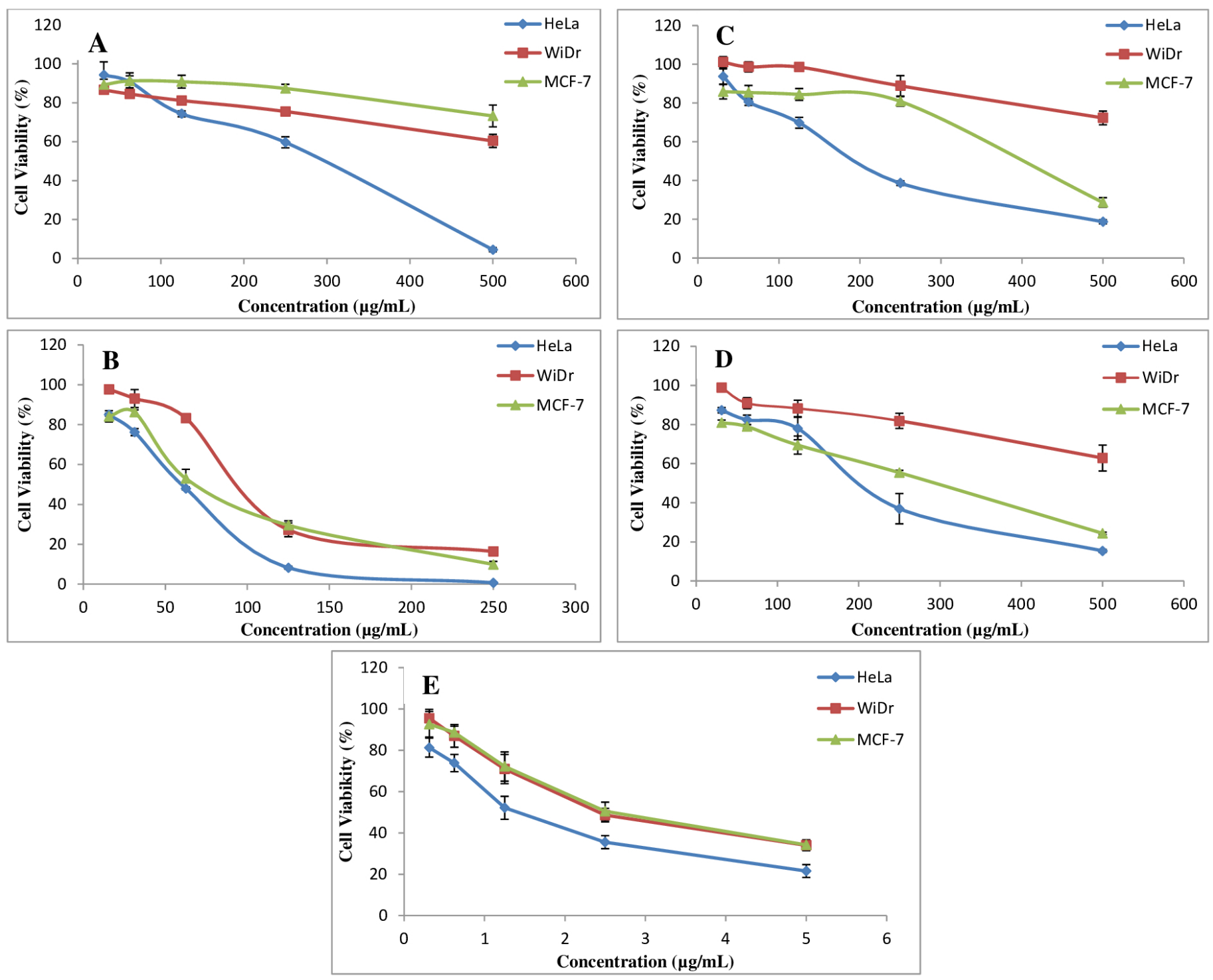

Figure 1. Correlation between samples' concentration against cell viability of three cancer cell lines. (A) HF, (B) EAF, (C) CE, (D) AEF and (E) Doxorubicin (PC). 


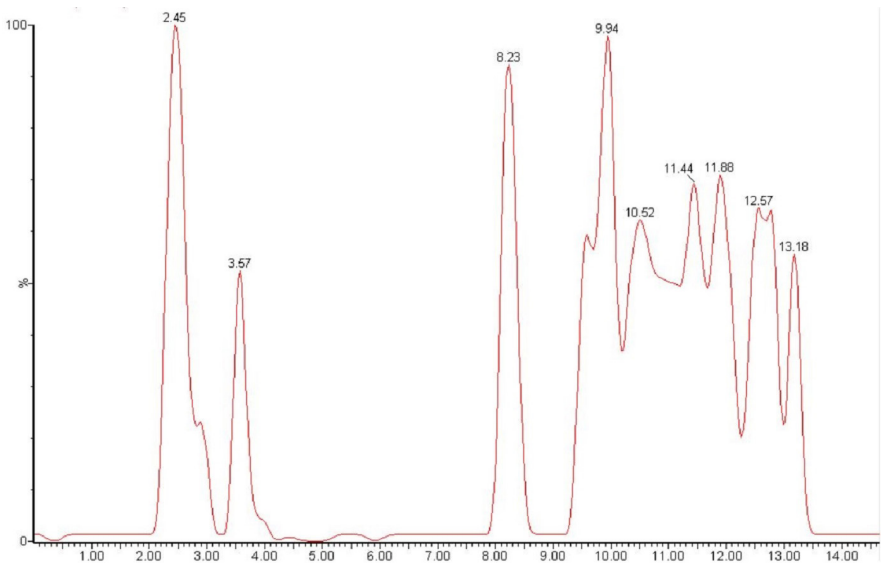

Figure 2. Chromatogram analysis of Ethyl Acetate Fraction by LC-MS.

of cancer cells depends on the concentration used; the higher the concentration of the test solution is, the less formazan crystals are formed and the lower the cell viability meaning that there are fewer living cells. Based on the results of cell viability obtained from each sample against cancer cells, the $\mathrm{IC}_{50}$ values were determined.

The cytotoxicity test results (Table 3 ) showed that $A$. ferox Copel tubers had the potential as the highest cytotoxic agent in the EAF towards HeLa cell line $(51.87 \mu \mathrm{g} / \mathrm{ml})$, WiDr cell line $(94.27 \mu \mathrm{g} / \mathrm{ml})$, and MCF-7 cell line $(68.12 \mu \mathrm{g} / \mathrm{ml})$ which were included in the moderate cytotoxic category. However, the HeLa cell also showed that the $\mathrm{CE}$ and AEF gave moderate category cytotoxic activity, whereas the cell types WiDr and MCF-7 showed that $\mathrm{CE}, \mathrm{HF}$, and $\mathrm{AEF}$ gave weak cytotoxic activity against WiDr and MCF-7 cell lines. However, the cytotoxic effects of extract and fractions were lesser than that of doxorubicin as a $\mathrm{PC}$ with very strong activity.

Based on the results of research on antioxidants and cytotoxic effects of cancer cells which showed that the EAF provided a good activity profile, the next stage is the analysis of the compound profile using LC-MS. LC-MS can be used to determine the secondary metabolite profile of EAF by observing ion spectrum products in the form of compound retention time and compound fragmentation based on $\mathrm{m} / \mathrm{z}$. The process of compound identification is based on the literature available on the LC-MS database and other pieces of supporting literature based on $\mathrm{m} / \mathrm{z}$ of compounds such as web applications RIKEN tandem mass spectral database (ReSpect for Phytochemicals, 2012) for phytochemicals.

The data in Table 4 show that the LC-ESI-MS analysis was prediction that compounds $(3,5$, and 6$)$ are phenolic derivate with $R_{\mathrm{t}} 8.23,10.52$, and 11.44, respectively. Compounds 3, 5 , and 6 showed molecular ion peak at $169.77 \mathrm{~m} / z[\mathrm{M}+\mathrm{H}]^{+}$ predicted as stilbenoid, 195.22 predicted as ferulic acid, and $203.7 \mathrm{~m} / z[\mathrm{M}+\mathrm{H}]^{+}$predicted as phenolic derivate [phenol,2,5-bis (1,1-dimethylethyl)]. Compounds 4, 8, and 9 were predicted are flavonoid compounds with $\mathrm{R}_{\mathrm{t}} 9.94,12.57$, and 13.18 , respectively. The amount of compounds is predicted as flavonoid/flavonols derivate based on the molecular ion peak at $178.22 \mathrm{~m} / z[\mathrm{M}+\mathrm{H}]^{+}$ in compound 4, $197.72 \mathrm{~m} / z[\mathrm{M}+\mathrm{H}]^{+}$in compound 8, and 566.07 $m / z[\mathrm{M}+\mathrm{H}]^{+}$in compound 9 (Kaempferol derivatives). The results of the identification analysis of chemical compounds using the LC-ESI-MS method with mode $[\mathrm{M}+\mathrm{H}]^{+}$on the EAF of $A$. ferox Copel tuber show that the EAF on average has a prediction of the high chemical content of phenolic and flavonoid compounds. The results of the chemical content screening based on the LCMS approach provide an overview of the compounds based on previous results. Nur et al. (2019) reported that the EAF of $A$.

Table 3. The $\mathrm{IC}_{50}$ values of samples towards cancer cell line.

\begin{tabular}{|c|c|c|c|c|c|c|c|}
\hline \multirow{2}{*}{ Cancer cell } & \multicolumn{6}{|c|}{ Concentration $(\mu \mathrm{g} / \mathrm{ml})$} & \multirow{2}{*}{$\mathrm{IC}_{50}$} \\
\hline & 15.625 & 31.25 & 62.5 & 125 & 250 & 500 & \\
\hline \multicolumn{8}{|l|}{$\mathrm{HeLa}$} \\
\hline $\mathrm{CE}$ & - & $93.76 \pm 3.93$ & $80.6 \pm 1.77$ & $69.83 \pm 2.82$ & $38.66 \pm 1.17$ & $18.72 \pm 1.12$ & 181.42 \\
\hline $\mathrm{HF}$ & - & $94.25 \pm 6.76$ & $90.76 \pm 3.08$ & $74.31 \pm 1.49$ & $59.67 \pm 2.85$ & $4.48 \pm 1.08$ & 202.69 \\
\hline EAF & $84.98 \pm 0.73$ & $76.24 \pm 1.75$ & $47.99 \pm 0.78$ & $8.26 \pm 0.71$ & $0.68 \pm 0.2$ & - & 51.87 \\
\hline $\mathrm{AEF}$ & - & $87.33 \pm 0.78$ & $82.4 \pm 2.82$ & $77.97 \pm 4.21$ & $36.96 \pm 3.87$ & $15.35 \pm 6.64$ & 180.23 \\
\hline $\mathrm{PC}$ & \multicolumn{7}{|c|}{$\mathrm{IC}_{50}(\mu \mathrm{g} / \mathrm{ml})=2.83$} \\
\hline \multicolumn{8}{|l|}{ WiDr } \\
\hline $\mathrm{CE}$ & - & $101.12 \pm 2.84$ & $98.69 \pm 2.59$ & $98.57 \pm 0.62$ & $88.90 \pm 5.27$ & $72.33 \pm 3.51$ & 869.83 \\
\hline $\mathrm{HF}$ & - & $86.59 \pm 1.13$ & $84.5 \pm 1.39$ & $81.15 \pm 1.14$ & $75.50 \pm 1.15$ & $60.39 \pm 3.36$ & 696.23 \\
\hline EAF & $97.76 \pm 0.87$ & $93.11 \pm 4.52$ & $83.29 \pm 1.72$ & $27.24 \pm 3.47$ & $16.37 \pm 2.14$ & - & 94.27 \\
\hline $\mathrm{AEF}$ & - & $98.87 \pm 1.34$ & $90.93 \pm 0.99$ & $88.24 \pm 4.62$ & $81.89 \pm 1.19$ & $62.87 \pm 0.59$ & 686.18 \\
\hline $\mathrm{PC}$ & \multicolumn{7}{|c|}{$\mathrm{IC}_{50}(\mu \mathrm{g} / \mathrm{ml})=2.63$} \\
\hline \multicolumn{8}{|l|}{ MCF-7 } \\
\hline $\mathrm{CE}$ & - & $85.87 \pm 3.73$ & $85.44 \pm 3.65$ & $84.5 \pm 3.03$ & $80.87 \pm 2.47$ & $28.68 \pm 2.48$ & 383.76 \\
\hline $\mathrm{HF}$ & - & $89.24 \pm 2.86$ & $91.19 \pm 4.17$ & $90.83 \pm 3.28$ & $87.35 \pm 2.14$ & $73.23 \pm 5.58$ & $1,176.67$ \\
\hline EAF & $84.16 \pm 2.83$ & $86.23 \pm 1.17$ & $52.98 \pm 4.59$ & $29.53 \pm 2.23$ & $9.87 \pm 1.52$ & - & 68.12 \\
\hline $\mathrm{AEF}$ & - & $80.96 \pm 1.36$ & $78.94 \pm 2.41$ & $69.49 \pm 5.75$ & $55.37 \pm 7.74$ & $24.33 \pm 0.79$ & 290.62 \\
\hline $\mathrm{PC}$ & \multicolumn{7}{|c|}{$\mathrm{IC}_{50}(\mu \mathrm{g} / \mathrm{ml})=3.33$} \\
\hline
\end{tabular}

Doxorubicin was used as PC. The data were expressed as mean \pm SD in triplicate $(n=3)$. 
Table 4. Identification of secondary metabolite products based on the prediction of ionic products from EAF.

\begin{tabular}{|c|c|c|c|c|}
\hline Compound & Group & Identified compounds & Rt (minutes) & Prediction $(m / z)$ by ReSpect for phytochemicals \\
\hline 1 & Glucose & Glucosinolate derivate & 2.45 & $156.11 ; 130.59 ; 117.28 ; 103.11 ; 102.20 ; 100.50 ; 99.84 ; 50.44$ \\
\hline 2 & Unknown & - & 3.57 & - \\
\hline 3 & Phenolic derivate & Stilbenoid & 8.23 & $169.77 ; 154.73 ; 142.37 ; 130.44 ; 124.89 ; 122.14 ; 101.88 ; 98.83 ; 54.75 ; 54.28$ \\
\hline 4 & Flavonoid & Flavonoid derivate & 9.94 & $178.22 ; 165.17 ; 151.10 ; 127.69 ; 116.12 ; 105.68 ; 10.87 ; 51.67$ \\
\hline 5 & Phenolic derivate & Ferulic acid & 10.52 & $195.22 ; 180.25 ; 158.90 ; 128.34 ; 103.91 ; 91.98 ; 88.21 ; 79.22 ; 69.58 ; 50.65$ \\
\hline 6 & Phenolic & Phenol,2,5-bis (1,1-dimethylethyl) & 11.44 & $203.70 ; 157.85 ; 146.50 ; 128.30 ; 125.73 ; 122.50 ; 110.58 ; 105.07 ; 91.58 ; 85.56 ; 72.66$ \\
\hline 7 & Terpenoid & Terpenoid derivate & 11.88 & $181.23 ; 176.44 ; 151.79 ; 131.67 ; 103.65 ; 102.56 ; 71.06 ; 66.28 ; 62.58 ; 55.58$ \\
\hline 8 & Flavonoid & Flavonoid derivate & 12.57 & $197.72 ; 158.83 ; 120.25 ; 105.68 ; 89.88 ; 85.71 ; 81.21 ; 65.12 ; 56.63 ; 51.34$ \\
\hline 9 & Flavonoid glycoside & Kaempferol derivatives & 13.18 & $566.07 ; 544.72 ; 498.68 ; 318.1 ; 271.06 ; 182.21 ; 133.05 ; 91.91 ; 75.86 ; 68.92 ; 65.23$ \\
\hline
\end{tabular}

ferox Copel had high phenolic and flavonoid levels of $17.55 \% \mathrm{w} / \mathrm{w}$ gallic acid equivalent and $0.14 \% w / w$ QE, respectively.

\section{DISCUSSION}

Angiopteris ferox Copel is a type of fern plant that has not been developed and published in terms of its pharmacological activity currently. Empirically, A. ferox Copel can be used in the treatment of cancer. In our study, an assessment of antioxidants and their cytotoxic effects on cancer cells was carried out. Several studies have examined that free radicals are the main cause of oxidative stress which can cause various types of diseases, one of which is cancer. There is some information on the use of antioxidants in the form of butyl hydroxyl toluene, butyl hydroxyl anisole, and gallate which actually have carcinogenic potential (da Silva \& Paiva, 2012; Pavithra et al., 2013). Therefore, we need active compounds derived from natural ingredients that have potential as antioxidants with safe side effects.

The antioxidant activity assay of extract and fractions of A. ferox Copel tuber was evaluated by ABTS, nitric oxide, and lipid peroxidation. All tests were carried out to determine the antioxidant capacity based on the mechanism and predicted chemical content in a sample. Antioxidant mechanisms were the most reported ones for the evaluation of antioxidant capacity derived from plants (Chen et al., 2017; Zheng et al., 2016). Determination of the activity of free radical scavenger can be done using quantitative ABTS colorimetric assay by measuring the absorbance of the sample using a spectrophotometer UV-Visible. ABTS radical scavenging assays are based on the decolorization of the blue color due to the reduction of ABTS radical by antioxidants (Mistriyani et al., 2018). The existence of the remaining blue color was measured at a wavelength of $752 \mathrm{~nm}$.

NO radical method is carried out to find out how much the ability of $\mathrm{CE}$ and its fractions to inhibiting the production of NO radicals in the body. In this case, the normal condition NO has a pathophysiological role in the body. However, if overproduction of NO can cause damage in the body such as inflammation, hypertension, and atherosclerosis, the NO method is one of the methods of testing antioxidant activity that describes the pathophysiology in the body (Boora et al., 2014; Chen et al., 2017; Pacher et al., 2007). The testing of antioxidant activity by the NO method is based on the attenuation of NO radicals produced by the presence of sodium nitroprusside in a phosphate buffer $\mathrm{pH}$ solution characterized by the formation of a purplish red color. NO radicals that are formed will be stabilized by antioxidant compounds. The suppression of NO radicals by antioxidant compounds causes color fading of radicals.

For lipid peroxidation assay by beta-carotene, degradation is an antioxidant test based on the color fading principle of beta-carotene by presenting radical products from the linoleic acid emulsion system. The product of linoleic acid in the form of hydroperoxide is a free radical formed during the incubation process at $50^{\circ} \mathrm{C}$. The degradation process of betacarotene can be directly proven by looking at the orange carotene color fading. The peroxide radical that is a linoleic acid product will attack the double bond conjugated from beta-carotene, which is the double bond that is responsible for the carotene orange color. The presence of an antioxidant compound from the sample will prevent the oxidation process of beta-carotene by peroxide radicals through a radical neutralization process by antioxidant compounds from a sample (Kulisic et al., 2004; Nur et al., 2017; Othman et al., 2007).

Blois (1958) described that antioxidant compounds are categorized as very strong if the $\mathrm{IC}_{50}$ value is less than $50 \mu \mathrm{g} / \mathrm{ml}$, strong antioxidants have $\mathrm{IC}_{50}$ values between 50 and $100 \mu \mathrm{g} / \mathrm{ml}$, moderate antioxidants have $\mathrm{IC}_{50}$ values between 100 and $150 \mu \mathrm{g} /$ $\mathrm{ml}$, and weak antioxidants have $\mathrm{IC}_{50}$ values of more than $150 \mu \mathrm{g} / \mathrm{ml}$.

The research showed that the EAF has a very strong activity in reducing free radicals in ABTS, NO, and BCB assay. AEF and CE show strong activity in ABTS and NO assay but not for BCB assay. In BCB assay, it was found that AEF had weak activity while $\mathrm{CE}$ had very strong activity. This occurs because the compounds in $\mathrm{CE}$ are multicomponent compounds ranging from low to high polarity which tend to be present in the lipid phase of beta-carotene emulsion so that it is easier to neutralize linoleic acid radicals when compared to AEF samples which may contain polar compounds which only tend to be present in the polar phase beta-carotene emulsion (Koleva et al., 2002; Kulisic et al., 2004). Then, HF shows weak activity to reduce free radical among ABTS, NO, and BCB assay. Nevertheless, PC quercetin showed a powerful antioxidant activity on ABTS, NO radical scavenging, and $\mathrm{BCB}$ assay. The use of quercetin is considered as a $\mathrm{PC}$ because it is a class of polyphenol compounds derived from flavonoids. The antioxidant strength of the EAF is influenced by the content of phenolic and flavonoids compounds. Flavonoids are secondary metabolite compounds derived from polyphenols which are generally found in plants and are the most effective antioxidant compounds in preventing various diseases (Choi et al., 2007; Chua et al., 2011). 
The study by Nur et al. (2019) described that the EAF has the highest level of flavonoids and phenolic when compared with $\mathrm{CE}$ and other fractions. Total phenolic levels from EAF were obtained, $17.55 \% \pm 0.953 \% \mathrm{w} / \mathrm{w}$ equivalent to gallic acid, and total flavonoid levels were obtained, $0.14 \pm 0.0006 \% \mathrm{w} / \mathrm{w}$ equivalent to quercetin. Phenolic and flavonoids from sample plants have a role to reduce ABTS, NO, and lipid peroxidation radical by hydrogen atom transfer mechanism (Apak et al., 2007). Evaluation of antioxidant activity using ABTS, NO, and lipid peroxidation methods is a method that describes the reactive mechanism of oxygen and nitrogen species in the body, where nitrogen, peroxide, and hydrogen radicals have a harmful effect in damaging cells in the body causing various diseases including cancer (Abdel-Hady et al., 2018; Zelickson et al., 2013). The antioxidant power possessed by $A$. ferox Copel has the potential to be developed in the treatment of diseases caused by oxidative stress such as cancer.

In this study, in vitro bioactivity as anticancer screening was also performed. In vitro cytotoxic tests as anticancer were carried out on each test sample using the MTT (Microtetrazolium) method. Cytotoxic test aims to determine the toxicity of a compound by observing decreased cell viability. The MTT method is a colorimetric test to measure cell metabolic activity based on the conversion of tetrazolium salt MTT to formazan in the mitochondria active on living cells. MTT will break into purple formazan (Kuete et al., 2017; Lü et al., 2012). The results of cytotoxic assay on microplate reader produced absorbance values at each concentration and the average value of the percentage of cancer cell death after being treated.

The $\mathrm{IC}_{50}$ value is a concentration value that results in $50 \%$ inhibition of cancer cell proliferation and shows the potential for toxicity of a compound to cells (Le Son \& Anh, 2013). According to Kuete et al. (2017), the $\mathrm{IC}_{50}$ value $<50 \mu \mathrm{g} / \mathrm{ml}$ is categorized as a strong cytotoxic effect; if the value of $50-<200$ $\mu \mathrm{g} / \mathrm{ml}$ is categorized as moderate cytotoxic, a value of $200-<1,000$ $\mu \mathrm{g} / \mathrm{ml}$ is categorized as a weak cytotoxic and $\mathrm{IC}_{50}$ values $>1,000$ $\mu \mathrm{g} / \mathrm{ml}$ do not have a cytotoxic effect. In the present study, EAF had shown higher activity in inhibiting the growth of cancer cells, that is, HeLa, WiDr, and MCF-7. Similar results were observed that EAF has a toxic effect against T47D cancer cell (Aisyah et al., 2020).

Based on the phytochemical screening that has been carried out, the $\mathrm{CE}$ and fraction of $A$. ferox Copel tuber contains flavonoids, tannins, saponins, steroids, and phenolic compounds. According to Woo and Kim (2013), there are several theories for the mechanism of flavonoids and phenolic as anticancer. Flavonoids and phenolic can function as anticancer by activating the apoptotic pathway of cancer cells. The mechanism of cell apoptosis in this theory is due to DNA fragmentation. This fragmentation begins with the release of the proximal DNA chain by reactive oxygen compounds such as hydroxyl radicals. Another effect is that flavonoids and phenolic as an inhibitor of tumor/ cancer proliferation are inhibiting protein kinase activity, thereby inhibiting the transduction pathway from the membrane to the nucleus cells. Flavonoids inhibit tyrosine kinase receptor activity because the increased activity of tyrosine kinase receptors plays a role in the growth of malignant cancer cells (Carocho \& Ferreira, 2013; Woo \& Kim, 2013).
This test can provide information on the types of secondary metabolites such as alkaloids, flavonoids, phenolics, steroids, saponins, and triterpenoids, making it easier to search for the main compounds that have bioactivity as antioxidants and anticancer.

\section{CONCLUSION}

This study provides information that A. ferox Copel has antioxidant activity that allows this plant to be developed as traditional medicine. In addition, the compounds contained in $A$. ferox Copel which had been predicted using LC-MS also have cytotoxic effects of three types of cancer cells, that is, HeLa, WiDr, and MCF-7. Therefore, our research has prospects to be developed.

\section{ACKNOWLEDGMENTS}

On this occasion, the authors would like to thank the Indonesian Ministry of Higher Education and Culture for providing research funding through higher education collaborative research grants "Hibah Kerjasama Perguruan Tinggi" with a contract number 231/SP2H/AMD/LT/DRPM/2020.

\section{CONFLICT OF INTEREST}

The authors declare that they have no conflict of interest.

\section{REFERENCES}

Abd El Hady F, Abdou AM, Abelaziz M. Isolation, identification and evaluation of antimicrobial and cytotoxic activities of the marine fungus Aspergillus unguis RSPG_204. Int J Pharm Sci Rev Res, 2014; 28:121-7.

Abd El Hady F, Abdou AM, Abelaziz M. Isolation, identification and evaluation of antimicrobial and cytotoxic activities of the marine fungus Aspergillus unguis RSPG_204. Int J Pharm Sci Rev Res, 2016; 5(9):2021-39.

Abdel-Hady H, El-Sayed MM, Abdel-Gawad MM, El-Wakil EA, Abdel-Hameed ESS, Abdel-Lateef EES. LC-ESI-MS analysis, antitumor and antioxidant activities of methanolic extract of Egyptian allium kurrat. J Appl Pharm Sci, 2018; 8(7):085-92.

Aisyah AN, Nur S, Lukitaningsih E, Rumiyati R, Burhan A, Adjara SM, Rahim K. Cytotoxic effects of paku atai merah (Angiopteris ferox Copel) tuber extract and fractions against T47D breast cancer cells. Galen J Pharm, 2020; 6(2):319-27.

Apak R, Güçlü K, Demirata B, Özyürek M, Çelik SE, Bektaşoğlu B, Berker KI, Özyurt D. Comparative evaluation of various total antioxidant capacity assays applied to phenolic compounds with the CUPRAC assay. Molecules, 2007; 12(7):1496-547.

Arnao MB, Cano A, Acosta, M. The hydrophilic and lipophilic contribution to total antioxidant activity. Food Chem, 2001; 73(2):239-44.

Blois MS. Antioxidant determinations by the use of a stable free radical [10]. Nature, 1958; 181:1199-200.

Boora F, Chirisa E, Mukanganyama S. Evaluation of nitrite radical scavenging properties of selected Zimbabwean plant extracts and their phytoconstituents. J Food Process, 2014; 2014:1-7.

Carocho M, Ferreira I. The role of phenolic compounds in the fight against cancer - a review. Anticancer Agents Med Chem, 2013; 13(8):1236-58.

Chen HL, Lan XZ, Wu YY, Ou YW, Chen TC, Wu WT. The antioxidant activity and nitric oxide production of extracts obtained from the leaves of Chenopodium quinoa willd. Biomedicine, 2017; 7(4):24.

Choi Y, Jeong HS, Lee J. Antioxidant activity of methanolic extracts from some grains consumed in Korea. Food Chem, 2007; 103(1):130-8; doi:10.1016/j.foodchem.2006.08.004

Chua LS, Latiff NA, Lee SY, Lee CT, Sarmidi MR, Aziz RA. Flavonoids and phenolic acids from Labisia pumila (Kacip Fatimah). Food Chem, 2011; 127(3):1186-92; doi.org/10.1016/j.foodchem.2011.01.122 
da Silva MCA, Paiva SR. Antioxidant activity and flavonoid content of Clusia fluminensis planch. \& Triana. An Acad Bras Cienc, 2012; 84(3):609-16; doi:10.1590/S0001-37652012000300004

Desai A, Qazi G, Ganju R, El-Tamer M, Singh J, Saxena A, Bedi Y, Taneja S, \& Bhat H. Medicinal plants and cancer chemoprevention. Curr Drug Metab, 2018; 9(7):581-91.

Emens LA, Middleton G. The interplay of immunotherapy and chemotherapy: harnessing potential synergies. Cancer Immunol Res, 2015; 3(5):436-43.

Eskander RN, Tewari KS. Immunotherapy: an evolving paradigm in the treatment of advanced cervical cancer. Clin Ther, 2015; 37(1):20-38.

Ghareeb MA, Shoeb HA, Madkour HMF, Refaey LAG, Mohamed MAM, Saad AM. Antioxidant and cytotoxic activities of Tectona grandis Linn. Leaves. Int J Phytopharmacol, 2014; 5(2):143-57.

Greenwell M, Rahman PKSM. Medicinal plants: their use in anticancer treatment. Int J Pharm Sci Res, 2015; 6(10):4103-12.

Harborne JB. Phytochemical methods a guide to modern tecniques of plant analysis. 3rd edition, Chapman \& Hall, London, UK, pp $54-84,1998$.

Helmy KY, Patel SA, Nahas GR, Rameshwar P. Cancer immunotherapy: accomplishments to date and future promise. Ther Deliv, 2013; 4(10):1307-20.

Hossain MA, AL-Raqmi KA, AL-Mijizy ZH, Weli AM, AlRiyami Q. Study of total phenol, flavonoids contents and phytochemical screening of various leaves crude extracts of locally grown Thymus vulgaris. Asian Pac J Trop Biomed, 2013; 3(9):705-10.

Hsiao YH, Lin CW, Wang PH, Hsin MC, Yang SF. The potential of Chinese herbal medicines in the treatment of cervical cancer. Integr Cancer Ther, 2019; 18(1):1-9.

Kokate KC. Practical pharmacognosy. 4th edition. Vallabh Prakashan, Delhi, India, p 218, 1997.

Koleva II, Van Beek TA, Linssen JPH, De Groot A, Evstatieva LN. Screening of plant extracts for antioxidant activity: a comparative study on three testing methods. Phytochem Anal, 2002; 13(1):8-17.

Kuete V, Karaosmanoğlu O, Sivas H. Chapter 10 - anticancer activities of African medicinal spices and vegetables (V. B. T.-M. S. and V. from A. Kuete ed.). Academic Press, Cambridge, MA, pp 271-97, 2017.

Kulisic T, Radonic A, Katalinic V, Milos M. Use of different methods for testing antioxidative activity of oregano essential oil. Food Chem, 2004; 85(4):633-40.

Le Son H, Anh NP. Phytochemical composition, in vitro antioxidant and anticancer activities of quercetin from methanol extract of Asparagus cochinchinensis (LOUR.) Merr. tuber. J Med Plants Res, 2013; 7(1):3360-6.

Lü L, Zhang L, Wai MSM, Yew DTW, Xu J. Exocytosis of MTT formazan could exacerbate cell injury. Toxicology in vitro, 2012; 26(4):636-44.

Mistriyani, Riyanto S, Rohman A. Antioxidant activities of rambutan (Nephelium lappaceum L) peel in vitro. Food Res, 2018; 2(1):119-23.

Nnanga N, Vandi D, Famen LN, Sidjui LS, Ngué SA, Sikadeu $\mathrm{S}$, Toghueo RMK, Nganso YOD, Mpondo EM. Phytochemistry and in vitro antimicrobial, antioxydant activities of Entandrophragma candollei $\mathrm{H}$. J Appl Pharm Sci, 2016; 6(05):73-9.

Nur S, Mubarak F, Jannah C, Winarni DA, Rahman DA, Hamdayani LA, Sami FJ. Total phenolic and flavonoid compounds, antioxidant and toxicity profile of extract and fractions of paku atai tuber (Angiopteris ferox Copel). Food Res, 2019; 3(6):734-40.
Nur S, Rumiyati R, Lukitaningsih E. Screening of antioxidants, anti-aging and tyrosinase inhibitory activities of ethanolic and ethyl acetate extracts of fruit flesh and fruit peel langsat (Lansium domesticum corr) in vitro. Majalah Obat Tradisional, 2017; 22(1):63.

Ochwang'i DO, Kimwele CN, Oduma JA, Gathumbi PK, Mbaria JM, Kiama SG. Medicinal plants used in treatment and management of cancer in Kakamega County, Kenya. J Ethnopharmacol, 2014; 151(3):1040-55.

Othman A, Ismail A, Abdul Ghani N, Adenan I. Antioxidant capacity and phenolic content of cocoa beans. Food Chem 2007; 100(4):1523-30.

Pacher P, Beckman JS, Liaudet L. Nitric oxide and peroxynitrite in health and disease. Physiol Rev, 2007; 87(1):315-424.

Pavithra GM, Siddiqua S, Naik AS, Prashith Kekuda TR, Vinayaka KS. Antioxidant and antimicrobial activity of flowers of wendlandia thyrsoidea, olea dioica, lagerstroemia speciosa and bombax malabaricum. J Appl Pharm Sci, 2013; 3(6):114-20.

Putram NM, Setyaningsih I, Tarman K, Nursid M. Anticancer activity from active fraction of sea cucumber. J Pengolahan Hasil Perikanan Indones, 2017; 20(1):53-62.

ReSpect for Phytochemicals. (2012). Available via http://spectra. psc.riken.jp/ (Accessed 08 July 2020).

Schwartsmann G, Ratain MJ, Cragg GM, Wong JE, Saijo N, Parkinson DR, Fujiwara Y, Pazdur R, Newman DJ, Dagher R, Di Leone L. Anticancer drug discovery and development throughout the world. J Clin Oncol, 2002; 20(12):475-595.

Seladji M, Bekhechi C, Beddou F, Dib H, Bendimerad N. Antioxidant activity and phytochemical screening of Nepeta nepetella aqueous and methanolic extracts from Algeria. J App Pharm Sci, 2014 4(02):012-016.

Unuofin JO, Otunola GA, Afolayan AJ. Polyphenolic content, antioxidant and antimicrobial activities of Vernonia mespilifolia Less. Used in folk medicine in the Eastern Cape Province, South Africa. J Evid Based Integr Med, 2018; 23(1):1-9.

Woo HD, Kim J. Dietary flavonoid intake and risk of stomach and colorectal cancer. World J Gastroenterol, 2013; 19(7):1011-9.

Zelickson BR, Ballinger SW, Dell'Italia LJ, Zhang J, DarleyUsmar VM. Reactive oxygen and nitrogen species: interactions with mitochondria and pathophysiology. In Lane MD, William J (ed.). Lennarz encyclopedia of biological chemistry. 2nd edition, Elsevier Science, Amsterdam, Netherlands, pp 17-22, 2013.

Zheng L, Zhao M, Xiao C, Zhao Q, Su G. Practical problems when using ABTS assay to assess the radical-scavenging activity of peptides: Importance of controlling reaction $\mathrm{pH}$ and time. Food Chem, 2016; 192(1):288-94.

\section{How to cite this article:}

Nur S, Aisyah AN, Lukitaningsih E, Rumiyati, Juhardi RI, Andirah R, Hajar AS. Evaluation of antioxidant and cytotoxic effect against cancer cells line of Angiopteris ferox Copel tuber and its compounds by LC-MS analysis. J Appl Pharm Sci, 2021; 11(08):054-061. 